\title{
Theorising Feminist Organising in and against Neoliberalism: Beyond Co-optation and Resistance?
}

\section{Introduction}

The literature on feminist activism in the neoliberal era is overwhelmingly preoccupied with cooptation and, correspondingly, by the incapacity of feminism to serve as a vector of resistance to neoliberal policies and logics. Concern over co-optation has simmered for a while. In the 1990s, feminist scholars working on gender and development pointed to the ascendancy of the NGO and its demobilising effects (e.g., Lang, 1997; Silliman, 1999), while others in sociology and cultural studies lamented the dawn of a 'post-feminist' age (e.g., Brooks, 1997). These arguments came together, and seemed to come to a head, in a spate of high-profile publications on co-optation in the mid-tolate 2000s (e.g., Fraser, 2009; Eisenstein, 2009). The sense of crisis has been tempered in more recent years by proclamations that feminism is making a comeback (e.g., Gill, 2016: 164; Aune and Redfern, 2013). Yet notwithstanding these tales of revival - or perhaps because of them - anxiety over feminism's vulnerability to appropriation by neoliberalism remain widespread (de Jong and Kimm, 2017). At the same time, albeit on a smaller scale, new possibilities for feminist resistance to neoliberalism are gaining attention (e.g., Elomäki and Kantola, 2017; Evans, 2016).

In what follows, we build on our earlier article interrogating high-profile publications on co-optation (Eschle and Maiguashca, 2014) to encompass a wider range of texts and bring both co-optation and resistance into the frame. In part one, we identify two rival contemporary co-optation discourses: a 'strong' version, which holds that feminism is slowly, but surely, being comprehensively 'undone' (McRobbie 2009), and a more nuanced narrative. While the latter is more convincing, it nonetheless replicates a partial view of neoliberalism and of feminist organising that leaves resistance in the shadows. In part two, we review recent literature charting current feminist resistances to the status quo, showing how this widens our lens on both neoliberalism and feminist organising yet still assumes that a large swathe of feminist organising is doomed to a co-opted fate. In effect, we suggest, contemporary scholarship on feminist organising in a neoliberal age is structured by a dichotomous understanding of feminism as either co-opted or resistant, serving to circumscribe our empirical understanding and political imagination. In part three, we point to ways in which it might be possible to move beyond this dichotomy by rethinking neoliberalism, what feminism is and where it takes place.

We acknowledge that our account of the literature is broad-brush, doing justice neither to the considerable overlaps between the rival narratives nor to individual contributions. However, our intention is to highlight the summative effect of the discourses in toto, and to indicate how that effect might be contested. Our suggestions for re-orientation remain tentative and open to further development. In that spirit, we hope this article is read as a constructive effort at ongoing engagement with an important field of feminist research.

\section{Tales of Feminist Co-optation}

We begin with the 'strong' co-optation thesis (Newman, 2013: 203). Briefly, proponents of this view, most influentially Fraser (2009), draw amongst other things on the longstanding debates about NGOisation and postfeminism mentioned above to argue that feminism has become the handmaiden of neoliberal capitalism. This is co-optation as a process of collective capitulation and, indeed, active collusion (see, inter alia, Power, 2009; Eisenstein, 2009; 2017; McRobbie, 2009; Jad, 2007). 
Although this tale of feminism undone is global in its scope, there is some attention to regional variation. In Northern contexts, the focus is on how feminists have provided discursive fodder for neoliberalism. Liberal feminist demands for the end of the 'family wage' and for the full integration of women into the labour market are blamed for justifying lower wages and benefits (Eisenstein, 2009, pp. 39-72; Fraser 2009), while their calls for women's freedom of choice, adopted wholesale in recent 'third wave' feminist celebrations of femininity (e.g., Power, 2009; McRobbie, 2009: 152158), are seen as reinforcing the neoliberal displacement of the engaged citizen with the individualised consumer. Taken together with the rise of so-called 'identity politics' and its concern with a culturally-focused 'politics of recognition', these developments have functioned not only to sideline the critique of capitalism within feminism, but also to limit feminist aspirations to matters of individual empowerment and cultural expression. In the South, 'NGOisation', with its accompanying short-termism and dependence on donor funding, is identified as the main cause of de-radicalisation (Jad, 2004; 2007; Silliman, 1999). To make matters worse, cutting across North and South, a process of 'gender mainstreaming' within state and interstate institutions has become the norm. This 'techno-managerial strategy' (McRobbie, 2009: 155-156) has brought 'gender experts' with a 'professional ethos of depoliticized expertise' (Fraser, 2009: 105) to the fore, displacing and defusing movement organising. The end result is that 'the dream of women's emancipation [has now been] harnessed to the engine of capitalist accumulation' (Fraser, 2009: 110-111).

This thesis has been thoroughly deconstructed (e.g., Funk, 2013; Sangster and Luxton, 2013; Newman, 2013), so we will limit our critique here to three broad points. The first concerns how neoliberal power relations are conceptualised. There is recognition by proponents of this approach that, along with being a class-based project to cut back on state powers, neoliberalism also has cultural dimensions, of which the production of the consumerist, entrepreneurial individualism is the capstone (e.g., McRobbie, 2009). However, as we have elaborated previously (Eschle and Maiguashca, 2014: 642), the strong thesis seems to us marked by a residual commitment to an economistic reading of change as driven by contradictions in the mode of production, with social and cultural relations conceived as secondary. Connectedly, neoliberalism is presented as a singular, unidirectional force that moves inexorably outward through space from the Northern core to the global South, leaving little room for contingency and contestation (Newman, 2013: 204). On such a view, it is hard to see how feminists could have resisted the gravity pull of neoliberal forces; more generally, this is an approach blind to the 'contradictions and paradoxes in capitalist social relations' (Aslan and Gambetti, 2011: 145) that feminists might exploit.

Our second concern is with the way in which the strong co-optation thesis conceives of the collective feminist subject. Pointing the finger primarily at liberal feminists for corrupting their movement, along with 'third -wave' feminists and proponents of 'identity politics', advocates of this view simultaneously lament the loss of the purer, more authentic form of politics represented by secondwave socialist feminists. This is contentious. Empirically speaking, conflating liberal feminism with neoliberal feminist formations underplays both the achievements and potential of the former, ignoring its long history of critical claims-making upon the state (Rottenberg, 2013). Equally, presenting socialist feminism as a bygone ideal misses not only the wide ranging activities of socialist feminists during the supposed period of co-optation - e.g., 'double militancy' in Latin America - but also the racialized and other exclusions generated within this movement. Indeed, a whole raft of feminist organising, past and present, North and South is left out of the picture, such as black feminism, anarcho-feminism, lesbian and queer feminism. More normatively speaking, the parsing of feminism into 'good girls' and 'bad girls' reproduces a 'politics of blame' (Newman, 2013: 203) with a disciplining and divisive effect on the feminist body (Weber, 1994). Differences between feminists are reified, positioned as absolute and irreconcilable, thus obscuring hard-won intrafeminist alliances. Given that the idealised 'good girls' have been left behind in the past and the 
shamed 'bad girls' dominate the present, there is also a nostalgic, backward-looking aspect to this policing dynamic that is particularly alienating to younger feminists (e.g., Coumans et al., 2017).

Turning finally to the question of where feminist activism takes place, we find the answer to be problematically narrow. The narrative focuses overwhelmingly on activism in formal institutional settings, equated in the North with global governance institutions and in the South with NGOs. This can be seen as a re-instantiation of familiar complaints against feminist activism located 'inside' the state, rather than 'outside', although on the strong co-optation thesis the institutional space regarded as intrinsically compromised has shifted outward and upward. As such, this account can be read as overly simplistic by critics arguing for a politics that is both 'in and against the state' (see, for example, debates in the UK in the 1980s, referenced by Newman, 2013: 208) or other governing bodies. More recently, the presentation of Southern NGOs as co-opted has been empirically contested, most notably by Alvarez who points to the ongoing 'movement work' of NGOs in the Latin American context (2009: 178) and charts the ways in which they have pushed back against neoliberal governance since the 1990s (see also Roy, 2015; 2017). In addition, the strong cooptation thesis has been accused of the 'total neglect' of feminist activism in the South outside of NGOs (Aslan and Gambetti, 2011: 131). In this way, it ends up,

call[ing] on feminists of the global North to develop a transnational feminist imaginary without asking them first to pay attention to the experiences of women from the South - as if there were no dialogue established between them, but above all, as if there was absolutely no conflict or contradiction among different feminist geographies. (Aslan and Gambetti, 2011: 132)

Thus the trouble with the strong co-optation thesis is not only its exclusionary and determinist reading of institutional sites of politics, but also its universalisation of particular Northern feminist visions of political possibility.

A second, more nuanced narrative of feminist co-optation has emerged in recent years, offering a partial corrective in its framing of neoliberalism, the collective feminist subject and where feminist activism takes place. To begin with the first of these, neoliberalism is conceptualised in at least three ways, with some scholars drawing explicitly on a historically materialist framework to understand it as a 'phase of capitalism' (Aslan and Gambetti, 2011: 144; Roberts, 2015), and others presenting it in Foucauldian terms as a 'form of governmentality' based on an individualising market logic. (Gill and Orgad, 2017; Rottenberg, 2013; Brown, 2015). A third position sees neoliberalism as a technocratic political project, driven primarily by a commitment to free markets, profit making and corporate interests (Kantola and Squires, 2012). What these perspectives share is the notion that while neoliberalism is a highly resilient, adaptable process, capable of appropriating a range of challenges and counter-narratives, it is also uneven, unpredictable and marked by contingency. As such it can yield a range of 'productive contradictions', including both opportunities for progressive change as well as new threats (Wood and Litherland, 2017: 3).

Navigating this unstable, complex terrain is a wider array of feminist protagonists, specified here in more detail. For, in addition to the role of 'femocrats' and 'gender experts' inside international institutions (Ferguson, 2015; Cornwall et al., 2008; Wilson, 2015), the nuanced literature identifies 'transnational business feminism' (Roberts, 2015), a new actor approaching gender inequality as a 'market problem' to be addressed by 'market solutions' (Calkin, 2015). It also zeroes in on 'neoliberal feminism', frequently associated with the widely read autobiography-cum-manifesto Lean In (Rottenberg, 2013; Williams, 2014; Lakämper, 2017). Encouraging elite women to push for their further advancement within the corporate world, neoliberal feminism is rebuked for displacing its older liberal feminist sister, as Rottenberg explains: 
Unlike classic liberal feminism whose raison d'être was to pose an immanent critique of liberalism, revealing the gendered exclusions within liberal democracy's proclamation of universal equality, particularly with respect to the law, institutional access, and the full incorporation of women into the public sphere, this new feminism seems perfectly in sync with the evolving neoliberal order. Neoliberal feminism, in other words, offers no critique immanent or otherwise - of neoliberalism. (Rottenberg, 2013: 219)

What these new instantiations of feminism share, according to the nuanced co-optation narrative, is an obsession with personal responsibility, individual empowerment and entrepreneurship (Baer, 2016; Gill and Orgad, 2017). In so doing, they turn away from the state as an agent of progressive change, neglect structural power dynamics including gendered, racialized and class inequalities (e.g., Williams, 2014; Hickel, 2014), and reduce the political to the personal, thereby contributing to the erosion of collective action against wider social injustices (e.g., Calkin, 2015).

In a similar vein to the strong thesis, this process of feminist de-politicisation is seen to acquire life and staying power within institutionalised settings. So Prügl (2015) focuses on the marketing activities of transnational companies, Rottenberg (2013) takes us inside corporations to the workplace and the boardroom, and Roberts (2015) includes a broad coalition of public and private spaces, including corporations, capitalist states, regional and international funding institutions, feminist actors and NGOs. Although some important texts focus on navigations of neoliberalised institutions within states, and in both the North and South (e.g., Newman, 2013; Lind, 2005), most of this literature locates the space of encounter between feminism and neoliberalism in the machinery of global corporate governance, centred in the North, but extending its tendrils outward into the South. It is noteworthy, however, that that state and interstate institutions are not an implacable 'iron cage' on this view. Rather they are conceived as variable and unpredictable sites marked by 'ambiguities and complexities' which can at times enable 'self-critique and reflexivity' on the part of 'gender experts' (Ferguson, 2015: 381-382) and produce collective benefits for women targeted by these same experts in certain specific cases (Prügl, 2015). In such accounts, institutional engagements have political possibilities, however hedged in with caveats and compromises.

We find this nuanced co-optation narrative to be more persuasive than its strong counterpart, offering as it does a sociologically sensitive and politically open-ended analysis. Nonetheless, we wish to raise some questions in regards to the three themes discussed above. Beginning with neoliberalism, while conceived in less monolithic terms, it is still treated as a unidirectional force, travelling outward from the North towards the South via elite global institutions. In this sense, while producing contradictory effects, neoliberalism is still presented as a fixed logic (whether framed in Marxist or Foucauldian terms), that threatens not only to colonise feminism as an actor, but also to neutralise cultural diversity across regions of the world. To this extent, certainly in the work focused on global governance institutions rather than individual states, political agency remains located primarily within the North.

Turning to the collective feminist subject, taken as a whole the nuanced approach duplicates the disciplining move of tagging some feminists as 'bad girls' who sell out. Moreover, precisely because advocates explicitly strive to avoid going down the route of determining a 'pure' or authentic feminism and reject, in particular, a reliance on nostalgia for this purpose (Calkin, 2017; Bernal and Grewal, 2017), we are given few hints as to what a non-co-opted feminism, or 'good girl', might look like. At best we are left to read this off its co-opted 'Other'. Thus, a feminism fit for the purpose of resisting neoliberalism, one deduces, must be collectively organised (Prügl, 2015) and oriented to challenging macro-economic policies (Roberts, 2015; Hickel, 2014) in the name of ending structural gender inequalities. For those who see neoliberalism in more Foucauldian terms, it is clear the battle 
must also be waged on the terrain of cultural and epistemic discourses, although it is difficult to see precisely how given the degree of saturation achieved by this all-embracing rationality (Brown, 2015). Either way, resistant feminism hovers over the text as an implicit ideal.

Finally, in regards to the sites of feminist politics, the underlying thread in both strong and nuanced approaches to co-optation is that the institutionalisation of feminism can pose as much of a threat to its vitality as neoliberalism, and that these two processes work hand in hand. And although the nuanced view allows for some push-back within institutions, and thus for feminist politics operating in and from these sites to be more or less co-opted, it seems clear that a fully resistant feminism can only occur outside them. To this extent, advocates of the nuanced approach sustain the 'inside/outside' framing of politics in which strategies for social change can only emerge from the latter. Moreover, just as in the strong co-optation narrative, the firm focus on institutions means that the political possibilities of extra-institutional spaces remain hidden from view. Finally, this narrowing of political scope is again reinforced by an assumed geopolitical division of political space, with an overwhelming focus on Northern-based and internationalised institutions of global governance as sites of agency, doing neoliberalism in the South. In this context, the voices, selfunderstandings and practices of women in the South both inside and beyond these organisations and any actual and potential resistance to neoliberalism in Southern contexts - remain largely obscured.

\section{Tales of Feminist Resistance}

In contrast, the smaller and more scattered body of literature that is the subject of the second part of this article moves resistance to the foreground of analysis. Although, we recognise geographically diverse antecedents, ${ }^{1}$ here we limit ourselves to the recent writings produced, at least in part, in response to the co-optation arguments surveyed above. Taken together, these texts bring into view a richer panoply of contemporary feminist organising.

We begin our discussion of this narrative with its account of neoliberalism. As with the nuanced cooptation discourse, we can discern both historical materialist and Foucauldian accounts, converging on a view of neoliberalism as a form of governmentality that entails the extension of neoliberal rule and rationality into greater areas of everyday life (Loveland, 2017: 69-79; Korolczuk, 2016: 33; Evans, 2015: 39-42). What is distinctive, however, is the centrality given to the intersections of neoliberalism with other power structures, particularly class, coloniality and white supremacism (e.g., Pratt, 2017; Carty and Mohanty, 2015). In addition, neoliberalism is analysed in ways that are more contextualised and sensitive to micro -level factors, such as country-specific austerity policies and their imbrications with racist discourses (Bassel and Emejulu, 2017; Stephenson, 2016; Elomäki and Kantola, 2017).

Moving on to what feminism looks like, several strands of organising missing from the previous two narratives come into sharp relief. So, for example, the battles, past and present, of socialist, Marxist, radical and green feminists are rendered visible (Luxton, 2014; Loveland, 2017) as are those aspects of 'third wave' feminism opposed to neoliberal capitalism (Evans, 2015; 2016). Perhaps the most conspicuous inclusion is women's organising around race/ethnicity and class identities. In an explicit effort to challenge the hegemonic stories of white, middle class feminism, a number of authors have set out to uncover the voices and experiences of communities thus far neglected in the co-opted literature.. For Bassel and Emejulu, for instance, recognising 'minority women's survival activism' is a necessary first step in moving toward more genuinely inclusive alliances (2017: 23, 78, 96; see also Harcourt et al., 2017; Carty and Mohanty, 2015; Pratt, 2017). Significantly, much of this work starts from the position that political activism is intrinsically a highly precarious, compromised endeavour. Thus Bassel and Emejulu (2017: chaps 4 and 5) highlight how minority women within British and 
French NGOs of the 'third sector' have to navigate the dangers posed by professionalization and competition, and that this delicate dance has to continue even in extra-institutional DIY spaces that remain vulnerable to state intervention. In such ways, a purist model of feminist activism is rejected in favour of a more complex understanding of the relation between resistance and power.

This inclusive, intricate mapping of the collective feminist subject is accompanied by a panoramic picture of where feminist struggles take place. Taking us away from the corporate boardroom and shiny buildings of international governance, this literature instead draws our attention to the wider world of national protest movements and community-based actions, in Turkey (Özgüler and Yarar, 2017), Egypt (Pratt, 2017) and beyond. We are reminded that feminists participate in an array of social movements, from the Spanish 'movement of squares' (e.g., Palomo, 2016) to Black Lives Matter (Jackson and Cohen, 2015; see also Eschle, forthcoming; Maiguashca et al., 2016). Last but not least, we are directed to online digital platforms as a site not only of 'clicktivism', but also of the dissemination of feminist histories and tactics, the creation of collective identities, and the planning of offline activism (see also Baer, 2016; Drüeke and Zobl, 2016; Zobl, 2009; Jackson and Cohen, 2015). Thus for Scharff et al, 'neoliberalism is not only redone but also undone in contemporary digital feminist activism' (2016: 8). On this account, then, the view of where feminist activism takes place is dramatically expanded outward from the Northern and institutional sites to which it is confined by co-optation narratives.

In sum, this third narrative of feminist resistance contains fruitful insights into the myriad of incremental and localised ways in which neoliberalism is being taken to task. Nonetheless, some limitations remain. To begin with, the account of neoliberalism here, focused as it is on the intersection with racialized and colonial power relations at the point of policy impact, tends to push our analytical gaze towards localised political processes and possibilities. While these are crucial, a fuller picture of neoliberalism must surely also incorporate the macro- and meso-level analyses of the more nuanced co-optation narrative.

With respect to the protagonist of this story, in a reversal of the previous narratives which emphasise the 'bad girls' of feminism, these texts hone in on forms of feminist resistance (the 'good girls'), this time with their co-opted versions allowed to linger in the background. What this approach shares with its counterparts, however, is the fact that it offers no explicit criteria for distinguishing between co-optation and resistance. Moreover, feminism appears as a disparate and localised set of activities. This is not surprising given the global reach and context-specific approach of this literature as well as its general eschewal of top-down and/or macro conceptions of resistance. Indeed, resistance tends to be described as 'an everyday practice that is shaped and motivated by people's attempts to find their own political, social and cultural positioning' and that finds expression through 'strategies for survival' (Harcourt et al., 2017: 6). Rooting resistance in marginalised individual subjectivities in this way, although an important reminder of the exclusionary character of the feminist label and the potentially colonising nature of 'global' feminist organising, leaves us with a big challenge. After all, given the implicit call of all three bodies of literature reviewed here for effective action against neoliberalism, it surely remains imperative to find a way to explore and create the conditions of possibility for these individual, resistant subjectivities to coalesce into forms of self-conscious, collective feminist organising - which disrupt not only neoliberal logics, but also white feminist frames.

Last but not least, although women's agency in the global South is restored to view by this resistance narrative, the emphasis is squarely on extra-institutional spaces: on community groups, street protests and online activism. And when formal institutional sites do come into play, we are told that political possibilities here are 'rapidly shrinking' due to the way neoliberalism has induced 'cut-throat relationships' between organisations and 'disciplined' practitioners (Bassel and Emejulu, 2017: 75). 
Indeed it is because of this that Bassel and Emejulu turn to the 'informal spaces' of minority women's activism, which may be 'depleted by austerity, sexism and racism but are also sites of resistance' (2017: 77, emphasis added). Thus, this narrative works similarly to the previous two: whether institutions are seen as entirely or partially co-opted, resistance is located elsewhere.

\section{Beyond Co-optation and Resistance?}

The previous two parts of this article have shown how co-optation and resistance narratives, even in their more nuanced and inclusive forms, set up binary choices between co-opted and resistant forms and sites of feminism. In this final part, we seek to open up a research agenda that would take us beyond dichotomous thinking on this topic, revisiting the conceptualisation of neoliberalism, what feminism is and where it takes place, with this in mind.

We begin with the conceptualisation of the collective feminist subject. As we have attempted to demonstrate, the juxtaposition of co-optation and resistance in the literature has produced a splitting of feminism into 'good girls' who lead the resistance and 'bad girls' who lead others astray with some recognition in the nuanced co-optation and resistance discourses of the more hybrid forms that sit in between. What is missing from the discussion is a sustained effort to think through the political implications of this disciplining move or to justify why certain kinds of feminist organising are evaluated as productive or problematic in the first place. This is despite the fact that the main self-appointed task of this literature is to adjudicate the contemporary state of feminism and, more specifically, to distinguish cases of vibrant feminisms from neoliberal impostors. Yet scholars chiefly concerned with co-optation either rely on nostalgia to identify their lost ideal of feminism or leave us to deduce a resistant feminism from descriptions of its co-opted twin. Scholars in the third camp, on the other hand, promote 'resistant' feminisms, but omit the criteria by which they champion one instance rather than another, remaining focused on marginalised subjectivities and the survival strategies enacted to defend them.

We recognise that this lack of definitional precision or reflection on how feminism as a collective actor is judged sound or wanting is not due to complacency or disinterest, but rather to a sense of urgency in the face of today's challenges. Yet without some sense of what feminism is for and against, at least in principle, it becomes impossible to engage in any meaningful evaluation of one particular instantiation of it. As we have argued elsewhere (Eschle and Maiguashca, 2014: 645-646), one way forward is to think of feminism as a crucial instantiation of left politics. Following Noberto Bobbio (1996), we define the left as a political project committed to upholding the 'emotive value of equality', understanding its opposite, i.e., inequality, to be a socially created problem, one that is sustained through 'customs, laws and coercion' (1996: 67), and that can and should be overturned through collective political action. Or, to put it another way, the left is animated by a moral objection to 'unjustifiable but remedial inequalities' and a desire to 'rectify' them (Lukes, 2003: 612) by means of 'a searching diagnosis, ... of the sources of unjustifiable discrimination', a 'practical programme to abolish or diminish them' and a collective will to resist their re-entrenchment (2003: 615). The left on this expansive conception cannot be conflated with traditional socialism and/or Marxism, but must be seen instead as embracing a wide range of other egalitarian movements, including feminism. Indeed, much of liberal feminism would be encompassed by this definition, an intuition chiming with Rottenberg's insight that 'all strands of feminism, even liberal feminism, have always operated, at least in theory, as a critique of the dominant political order' (2013: 432).

Situating feminism firmly on the left in this way allows us to make two important moves with regard to thinking about the relationship between feminism and neoliberalism. First, it permits us to insist on the centrality of intersectionality as a political aspiration of feminism and indeed of the left more widely. This is because inequalities are cross-cutting and mutually reinforcing, as black feminists, 
among others, have reminded us (Crenshaw, 1991; Hill Collins and Bilge, 2016). Thus struggling against gender oppression requires us to examine how it is reinforced and complicated by other axes of power. Despite claims that intersectionality has now become a commonly accepted principle amongst feminists (Hancock, 2016), it seems to be lacking in much of the first two narratives we examined above, perhaps because, as Inderpal Grewal warns, 'the language of co-optation suggests a need for a pure subject of feminism... or even a desire for an autonomous movement whose sole vector is gender' (Grewal in Roy, 2017: 255, emphasis added).

If feminism is understood as speaking to and from a left political project, then we can defend a second claim: that it embodies in all its varieties a form of resistance to neoliberalism and the attendant inequalities that it produces and sustains. This chimes with the few hints scattered across the literature attempting to capture what feminism, in its 'good girl' instantiation, is for - e.g., social justice and liberation (Farris and Rottenberg, 2017: 6), autonomy and equality, individual and collective empowerment (Schild, 2015), or economic redistribution and support for public services (Evans, 2016). In such ways, these authors are defending a normative vision of feminism as posing a fundamental challenge to neoliberalism. To this extent, it seems to us that the term 'neoliberal feminism', (or 'transnational business feminism', or 'market feminism') is an oxymoron. ${ }^{2}$

This is not to deny that something problematic is going on with the emergence of phenomena associated with 'neoliberal feminism 'and the like. It is simply to suggest that the adoption of a different terminology, such as 'post-feminist', to describe it (McRobbie, 2009; Gill, 2007). Perhaps future research should also distinguish more carefully between the co-optation of feminist actors, understood as a process of conversion, and the appropriation of feminist ideas, understood as a process of hijacking or instrumentalising something that is not one's own. While the former requires the participation, witting or unwitting, of self-identified feminist subjects, the latter makes no such demands and can be undertaken by avowed non-feminists to non-feminist ends. Both processes are subsumed under the general charge of co-optation across all three bodies of literature (Calkin, 2017), but disentangling them might help scholars to clarify what is at stake politically as well as to distinguish empirically between feminist and non-feminist (or post-feminist) actors.

At this point, we should admit that defining a politics solely in terms of its aspirations or vision is to circumscribe debate about its character and implications unduly. Locating feminism on the left tells us nothing about either the political practices it enacts in particular places at particular times, or their consequences, which may be intended or unintended. Thus, an arguably feminist-inspired practice can result in what some will see as non-feminist outcomes; conversely, as Prügl (2015) reminds us, a decidedly non-feminist corporate-sponsored project designed to increase sales can create productive openings for collective empowerment. In our previous writings, we sought to develop normative criteria for evaluating the practices and outcomes of feminist activism (Eschle and Maiguashca, 2014: 646-647; Maiguashca, 2011), and there is a much wider literature on movement tactics and outcomes worth studying to this end. Here we limit ourselves to saying that more work needs to be undertaken to distinguish between intent, practice and impact, and to reflect on criteria for evaluating each, when making judgements about the potential of particular feminist engagements.

Now we turn more briefly to the question of where feminist activism takes place. We have shown above that the co-optation/resistance dichotomy is buttressed on this point by the inside/outside binary, despite the fact that the assumptions at work have been challenged conceptually and empirically, including by scholars stressing the political ambiguity of NGOs and their increasing reconnection to movement politics. This message does not seem to have been widely received, however, and there is clearly scope for closer empirical study of the diversity of feminist NGOs in specific contexts. Such research should take seriously Alvarez's claim that 'though 
professionalization and institutionalization ... represent their own vexing challenges..., they do not in themselves determine the type of feminist practices that are prioritized by NGOs' (Alvarez, 2009: 182).

Reaching beyond NGOs to the wider terrain of global governance, and taking inspiration from the resistance literature, we think more work could be done to excavate the contestation possible in this highly institutionalised terrain. One possible resource for this line of inquiry might be the frameworks and tools developed in the school of feminist institutionalism (e.g., Mackay et al., 2010; Kenny, 2014). Here we find an emphasis on institutions as both stratified by gender and productive of it, and as sites of feminist engagement as well as of constraint. Importantly, we also find an expansive definition of institutions as formal and informal 'rules of the game', making it difficult to sustain clear boundaries between institutional and extra-institutional politics. Instead, it becomes pertinent to enquire into the extent to which routinisation and sedimentation of procedures and cultural norms may shape activism both inside the organisations of global governance - and beyond. Another way forward is suggested by the 'border work' concept propounded by Newman (2013: 216), or by the ethnographic, bottom-up approach of Bassel and Emejulu (2018). Close attention to the autobiographical narratives of activists in this vein can reveal often unpredictable impacts at a personal level as well as the wider paradoxes and challenges of institutional engagement (see also Ferguson, 2015).

Finally, we turn to the conceptualisation of neoliberalism. For, although in a less obvious way than the other two themes we have discussed, residual traces of binary thinking are detectable here as well. Neoliberalism and feminism are juxtaposed to each other as ontologically separate forces, even if neoliberalism is seen by some to have differentiated, unpredictable effects when it attempts to consume its foe. The image here is of a power struggle between two discrete entities in which one side gains at the expense of the other (see also Newman, 2013: 204-205). We want instead to reach for an understanding of neoliberalism that allows us to see how feminism (and other contemporary social movements) are not external to it and never entirely innocent of its power dynamics, even while simultaneously seeking to overturn its most egregious effects.

Conveniently, there is considerable feminist scholarship to help us see the dynamics of neoliberalism differently. So, for example, one could take a 'bottom up' approach, investigating neoliberalism from the point of view of feminist resistances against it (Abu-Lughod, 1990; Enloe, 1996). As Abu-Lughod argues, 'In the rich and sometimes contradictory details of resistance the complex workings of social power can be traced' (1990: 42). Making feminist oppositional practices a 'diagnostic' of neoliberalism in this way (1990: 42) might help us to dissolve its ontological integrity. A contrasting research strategy would be to enquire further into the gendered and racialized constitution of neoliberal capitalism (Gill and Orgad, 2017; Brown, 2015), albeit with more focus on the 'cracks and fissures in the neoliberal "order of things"' (Harcourt et al., 2017: 8). A final approach is offered by the creative feminist work of Gibson-Graham (1996), which draws on a mix of poststructuralist and Marxist insights to deconstruct understandings of capitalism as a unitary force. As these authors explain, 'it is the way capitalism has been thought that has made it so difficult to imagine its supersession' (1996: 4). Whatever route we take, we should learn from Gibson-Graham when they say: 'We hear the left is in disarray ... Part of what produces this disarray is the vision of what the left is arrayed against' (1996: 263). By unravelling neoliberal capitalism as a unitary actor, we can think more generously about the possibilities of feminist transformation, understood as a leftinspired project.

\section{Conclusion}


In this article, we have grouped the literature on feminist organising in and against neoliberalism into three broad narratives: a strong co-optation thesis that is opposed by a more nuanced cooptation discourse and an emergent but significant resistance narrative. While we are more sympathetic to the latter two, we have shown that all three hinge on a binary division of feminism into co-opted and resistant faces that each gain their meaning from the other, and in this way present us with stark choices between incommensurable political poles. Indeed, it could be argued that the literature is reviving the reform/revolutionary dichotomy of old. In so doing, it relies on a number of other unhelpful binaries: the 'good girls' vs. 'bad girls' parsing of the feminist subject for one, and the juxtaposition between institutional politics to grassroots activism, or inside to outside, a prominent second. There is also an implicit binary set up between the core subjects under discussion, feminism and neoliberalism. In this way, we are presented with a view of feminism as sundered into forms that are either co-opted or resistant, and either surrendered to neoliberalism or beyond its clutches, thus limiting both our empirical picture of feminist organising and our conceptualisation of its political constraints and possibilities.

In response, we have indicated fresh lines of enquiry. These include, among other things, the suggestion that scholars reconceptualise feminism as on the left and thereby egalitarian in ethos and intrinsically opposed to the inequalities generated by neoliberalism; that they pay further attention to the ambiguities of NGOs and the contested character and porousness of institutional sites of politics; and that they reconfigure analyses of neoliberalism in more bottom up, fully intersectional and disaggregated ways. Thus, we hope to have sketched out a research agenda that moves us beyond binary argumentation to yield a more empirically accurate and politically open-ended picture of feminism. Re-envisaging feminism as a collective, left-wing struggle, manifested in a range of sites, and entangled but never entirely captured within the complex weave of neoliberal power relations, allows us to see that feminist organising is not either/or but rather both inescapably constituted by its neoliberal context and continually attempting to reframe and overturn neoliberal logics and effects.

\section{Acknowledgements}

A draft of this paper was presented at the International Studies Association annual convention, San Francisco, April 2018 and thanks are due to participants for their help in clarifying some of the key arguments. We are also grateful to the editors of EJPG for the opportunity to contribute to this inaugural issue, and to our anonymous reviewers for their constructive feedback.

\section{Notes}

\footnotetext{
${ }^{1}$ These include documentation of feminist-inflected opposition since the 1980s to SAPs in the South, welfare restructuring in the North and the operation of multinational corporations and free trade zones and agreements across both (e.g., Rowbotham and Linkogle, 2001; Eschle and Maiguashca, 2010; Domínguez Reyes, 2014; Naples and Desai, 2002).

${ }^{2}$ In this way, we draw a boundary not between good and bad feminists, but between feminist and nonfeminist.
}

\section{References}

Abu-Lughod, L. 1990. 'The Romance of Resistance: Tracing Transformations of Power through Bedouin Women', American Ethnologist 17 (1), 41-55.

Alvarez, SE. 2009. 'Beyond Ngo-Ization? Reflections from Latin America', Development 52 (2), 175-184. 
Aslan, Ö \& Gambetti, Z. 2011. 'Provincializing Fraser's History: Feminism and Neoliberalism Revisited', History of the Present 1 (1), 130-147.

Aune, K \& Redfern, C. 2013. Reclaiming the F Word: Feminism Today. 2nd edition, London: Zed Books.

Baer, H. 2016. 'Redoing Feminism: Digital Activism, Body Politics and Neoliberalism', Feminist Media Studies 16 (1), 17-34.

Bassel, L \& Emejulu, A. 2017. Minority Women and Austerity: Survival and Resistance in France and Britain. Bristol: Policy Press.

Bassel, L \& Emejulu, A. 2018. 'Caring Subjects: Migrant Women and the Third Sector in England and Scotland', Ethnic and Racial Studies 41 (1), 36-54.

Bernal, V \& Grewal, I. 2017. 'Introduction - the Ngo Form, Feminist Struggles, States and Neoliberalism', in Bernal, V. \& Grewal, I. (eds) Theorizing Ngos: States, Feminisms and Neoliberalisms. pp.1-16. Durham, NC: Duke University Press.

Bobbio, N. 1996. Left and Right: The Importance of a Political Distinction. Cambridge: Polity Press.

Brooks, A. 1997. Postfeminisms: Feminism, Cultural Theory and Cultural Forms. London and New York: Routledge.

Brown, W. 2015. Undoing the Demos: Neoliberalism's Stealth Revolution. MIT Press.

Calkin, S. 2015. 'Post-Feminist Spectatorship and the Girl Effect: "Go Ahead, Really Imagine Her"', Third World Quarterly 36 (4), 654-669.

Calkin, S. 2017. 'Disrupting Disempowerment: Feminism, Co-Optation and the Privatised Governance of Gender and Development', New Formations (91), 69-86.

Carty, L \& Mohanty, CT. 2015. 'Mapping Transnational Feminist Engagements: Neoliberalism and the Politics of Solidarity', in Baksh, R., Harcourt, W., Carty, L. \& Mohanty, C. T. (eds) The Oxford Handbook of Transnational Feminist Movements. Oxford: Oxford University Press.

Cornwall, A, Gideon, J \& Wilson, K. 2008. 'Introduction: Reclaiming Feminism: Gender and Neoliberalism', IDS Bulletin 39 (6), 1-9.

Coumans, SV, Harcourt, W \& Keysers, L. 2017. 'An Intergenerational Trialogue on Global Body Politics', in Harcourt, W. (ed.) Bodies in Resistance: Gender and Sexual Politics in the Age of Neoliberalism. pp.213-233. Basingstoke: Palgrave Macmillan.

Crenshaw, K. 1991. 'Mapping the Margins: Intersectionality, Identity Politics, and Violence against Women of Color', Stanford Law Review 43 (6), 1241-1299.

de Jong, S \& Kimm, S. 2017. 'The Co-Optation of Feminisms: A Research Agenda', International Feminist Journal of Politics 19 (2), 185-200.

Domínguez Reyes, E. 2014. 'Women Organizing against Free Trade in Latin America', Latin American Policy 5 (2), 193-206.

Drüeke, R \& Zobl, E. 2016. 'Online Feminist Protest against Sexism: The German-Language Hashtag \#Aufschrei', Feminist Media Studies 16 (1), 35-54.

Eisenstein, H. 2009. Feminism Seduced: How Global Elites Use Women's Labor and Ideas the Exploit the World. Boulder and London: Paradigm Publishers.

Eisenstein, H. 2017. 'Hegemonic Feminism, Neoliberalism and Womenomics: 'Empowerment' Instead of Liberation?', New Formations: a journal of culture/theory/politics 91, 35-49.

Elomäki, A \& Kantola, J. 2017. 'Austerity Politics and Feminist Resistance in Finland: From Established Women's Organizations to New Feminist Initiatives', in Kantola, J. \& 
Lombardo, E. (eds) Gender and the Economic Crisis in Europe: Politics, Institutions and Intersectionality. pp.231-255. Basingstoke: Palgrave Macmillan.

Enloe, C. 1996. 'Margins, Silences and Bottom Rungs: How to Overcome the Underestimation of Power in the Study of International Relations', in Booth, K., Zalewski, M. \& Smith, S. (eds) International Theory: Positivism and Beyond. pp.186202. Cambridge: Cambridge University Press.

Eschle, C. forthcoming. 'Troubling Stories of the End of Occupy: Feminist Narratives of Betrayal at Occupy Glasgow', Social Movement Studies.

Eschle, C \& Maiguashca, B. 2010. Making Feminist Sense of the Global Justice Movement. Lanham: Rowman and Littlefield.

Eschle, C \& Maiguashca, B. 2014. 'Reclaiming Feminist Futures: Co-Opted and Progressive Politics in a Neo-Liberal Age', Political Studies 62 (3), 634-651.

Evans, E. 2015. The Politics of Third Wave Feminisms: Neoliberalism, Intersectionality, and the State in Britain and the Us. Basingstoke: Palgrave.

Evans, E. 2016. 'Feminist Resistance', Renewal: A Journal of Labour Politics 24 (3).

Farris, S \& Rottenberg, C. 2017. 'Introduction: Righting Feminism', New Formations: A Journal of Cultural Theory/Politics (91), 5-15.

Ferguson, L. 2015. '“This Is Our Gender Person"', International Feminist Journal of Politics 17 (3), 380-397.

Fraser, N. 2009. 'Feminism, Capitalism and the Cunning of History', New Left Review (56), 97-117.

Funk, N. 2013. 'Contra Fraser on Feminism and Neoliberalism', Hypatia 28 (1), 179-196.

Gibson-Graham, JK. 1996. The End of Capitalism (as We Knew It): A Feminist Critique of Political Economy. Minneapolis, MN: London: University of Minnesota Press.

Gill, R. 2007. 'Postfeminist Media Culture:Elements of a Sensibility', European Journal of Cultural Studies 10 (2), 147-166.

Gill, R. 2016. 'Post-Postfeminism?: New Feminist Visibilities in Postfeminist Times', Feminist Media Studies 16 (4), 610-630.

Gill, R \& Orgad, S. 2017. 'Confidence Culture and the Remaking of Feminism', New Formations: A Journal of Cultural Theory/Politics (91), 16-34.

Hancock, A-M. 2016. Intersectionality: An Intellectual History. Oxford: Oxford University Press.

Harcourt, W, Heumann, S \& Asya, A. 2017. 'Introduction', in Harcourt, W. (ed.) Bodies in Resistance: Gender and Sexual Politics in the Age of Neoliberalism. pp.1-21. London: Palgrave Macmillan UK.

Hickel, J. 2014. 'The "Girl Effect": Liberalism, Empowerment and the Contradictions of Development', Third World Quarterly 35 (8), 1355-1373.

Hill Collins, P \& Bilge, S. 2016. Intersectionality. Cambridge: Polity.

Jackson, SJ \& Cohen, C. 2015. 'Ask a Feminist: A Conversation with Cathy Cohen on Black Lives Matter, Feminism, and Contemporary Activism'. Signs: Journal of Women in Culture and Society. Available online at: http://signsjournal.org/ask-a-feministcohen-jackson/, [Accessed 30/12 2017].

Jad, I. 2004. 'The Ngo-Isation of Arab Women's Movements', IDS Bulletin 35 (4), 34-42. Jad, I. 2007. 'Ngos: Between Buzzwords and Social Movements', Development in Practice 17 (4-5), 622-629.

Kantola, J \& Squires, J. 2012. 'From State Feminism to Market Feminism?', International Political Science Review 33 (4), 382-400. 
Kenny, M. 2014. 'A Feminist Institutionalist Approach', Politics \& Gender 10 (4), 679-684. Korolczuk, E. 2016. 'Neoliberalism and Feminist Organizing: From " Ngo-Ization of Resistance " to Resistance against Neoliberalism', in Kovats, E. (ed.) Solidarity in Struggle. Feminist Perspectives on Neoliberalism in East-Central Europe. pp.32-41. Budapest: Friedrich-Ebert-Stiftung.

Lakämper, J. 2017. 'Affective Dissonance, Neoliberal Postfeminism and the Foreclosure of Solidarity', Feminist Theory 18 (2), 119-135.

Lang, S. 1997. 'The Ngoization of Feminism: Institutionalization and Institution Building within the German Women's Movements', in Scott, J., Kaplan, C. \& Keates, D. (eds) Transitions, Environments, Translations: Feminism in International Politics,. London: Routledge.

Lind, A. 2005. Gendered Paradoxes: Women's Movements, State Restructuring, and Global Development in Ecuador. Pennsylvania: Pennsylvania State University Press.

Loveland, K. 2017. 'Feminism against Neoliberalism: Theorising Biopolitics in Germany, 1978-1993', Gender \& History 29 (1), 67-86.

Lukes, S. 2003. 'Epilogue: The Grand Dichotomy of the Twentieth Century', in Ball, T. \& Bellamy, R. (eds) The Cambridge History of Twentieth Century Political Thought. pp.602-626. Cambridge: Cambridge University Press.

Luxton, M. 2014. 'Marxist Feminism and Anticapitalism: Reclaiming Our History, Reanimating Our Politics', Studies in Political Economy 94 (1), 137-160.

Mackay, F, Kenny, M \& Chappell, L. 2010. 'New Institutionalism through a Gender Lens: Towards a Feminist Institutionalism?', International Political Science Review 31 (5), 573-588.

Maiguashca, B. 2011. 'Looking Beyond the Spectacle: Social Movement Theory, Feminist Anti-Globalization Activism and the Praxis of Principled Pragmatism', Globalizations 8 (4), 535-549.

Maiguashca, B, Dean, J \& Keith, D. 2016. 'Pulling Together in a Crisis? Anarchism, Feminism and the Limits of Left-Wing Convergence in Austerity Britain', Capital \& Class 40 (1), 37-57.

McRobbie, A. 2009. The Aftermath of Feminism: Gender, Culture and Social Change. London: Sage.

Naples, N \& Desai, M. 2002. Women's Activism and Globalization: Linking Local Politics and Transnational Struggles. London: Routledge.

Newman, J. 2013. 'Spaces of Power: Feminism, Neoliberalism and Gendered Labor', Social Politics: International Studies in Gender, State and Society 20 (2), 200-221.

Özgüler, C \& Yarar, B. 2017. 'Neoliberal Body Politics: Feminist Resistance and the Abortion Law in Turkey', in Harcourt, W. (ed.) Bodies in Resistance: Gender and Sexual Politics in the Age of Neoliberalism. pp.133-161. London: Palgrave Macmillan UK.

Palomo, E. 2016. 'Austerity Policies and the Feminist Movement in Spain', Globalizations 13 (6), 925-927.

Power, N. 2009. One-Dimensional Woman. London: Zero Books.

Pratt, N. 2017. 'Gendering Resistance to Neoliberal Restructuring: The Case of Egypt', Paper Presented At International Studies Association annual convention. 22-25 February, Baltimore.

Prügl, E. 2015. 'Neoliberalising Feminism', New Political Economy 20 (4), 614-631.

Roberts, A. 2015. 'The Political Economy of "Transnational Business Feminism"', International Feminist Journal of Politics 17 (2), 209-231. 
Rottenberg, C. 2013. 'The Rise of Neoliberal Feminism', Cultural Studies 28 (3), 418-437. Rowbotham, S \& Linkogle, S. 2001. Women Resist Globalization: Mobilizing for Livelihood and Rights. London: Zed Books.

Roy, S. 2015. 'The Indian Women's Movement:Within and Beyond Ngoization', Journal of South Asian Development 10 (1), 96-117.

Roy, S. 2017. 'The Positive Side of Co-Optation? Intersectionality: A Conversation between Inderpal Grewal and Srila Roy', International Feminist Journal of Politics 19 (2), 254262.

Sangster, J \& Luxton, M. 2013. 'Feminism, Co-Optation and the Problems of Amnesia: A Response to Nancy Fraser', Socialist Register 49, 288-309.

Scharff, C, Smith-Prei, C \& Stehle, M. 2016. 'Digital Feminisms: Transnational Activism in German Protest Cultures', Feminist Media Studies 16 (1), 1-16.

Schild, V. 2015. 'Feminism and Neoliberalism in Latin America', New Left Review 96, 59-74.

Silliman, J. 1999. 'Expanding Civil Society: Shrinking Political Spaces - the Case of Women's Nongovernmental Organisations', Social Politics 6 (1), 23-53.

Stephenson, M-A. 2016. 'Feminist Challenges to Austerity', Globalizations 13 (6), 915-918.

Weber, C. 1994. 'Good Girls, Little Girls and Bad Girls: Male Paranoia in Robert Keohane's Critique of Feminist International Relations', Millennium: Journal of International Studies 23 (2), 337-349.

Williams, C. 2014. 'The Happy Marriage of Capitalism and Feminism', Contemporary Sociology 43 (1), 58-61.

Wilson, K. 2015. 'Towards a Radical Re-Appropriation: Gender, Development and Neoliberal Feminism', Development and Change 46 (4), 803-832.

Wood, R \& Litherland, B. 2017. 'Critical Feminist Hope: The Encounter of Neoliberalism and Popular Feminism in Wwe 24: Women's Evolution', Feminist Media Studies, 1-18.

Zobl, E. 2009. 'Cultural Production, Transnational Networking, and Critical Reflection in Feminist Zines', Signs: Journal of Women in Culture \& Society 35 (1), 1-12. 